\title{
Hubungan antara Gejala Gangguan Depresi dan Tension-Type Headache (TTH): Studi Eksploratif
}

\author{
Cecilia J. Setiawan, ${ }^{1}$ Henny Anggraini Sadeli, ${ }^{2}$ Tuti Wahmurti A. Sapiie ${ }^{3}$ \\ ${ }^{1}$ Rumah Sakit Awal Bros Cikokol Tangerang, ${ }^{2}$ Departemen Ilmu Saraf Fakultas Kedokteran \\ Universitas Padjadjaran, ${ }^{3}$ Departemen Ilmu Kedokteran Jiwa Fakultas Kedokteran Universitas \\ Padjadjaran Rumah Sakit Dr. Hasan Sadikin Bandung
}

\begin{abstract}
Abstrak
Prevalensi gangguan depresi semakin meningkat, termasuk yang berkomorbiditas dengan penyakit fisik. Kondisi medik yang telah lama dikaitkan dengan gangguan depresi adalah tension-type headache (TTH). Komorbiditas ini berhubungan dengan perjalanan penyakit TTH kronik. Tujuan penelitian ini untuk mengetahui gejala gangguan depresi yang paling banyak terjadi pada penderita TTH serta menganalisis hubungan antara gejala tersebut dan tipe TTH yang dialaminya. Penelitian ini merupakan studi potong lintang terhadap 32 penderita TTH yang berobat jalan ke Instalasi Rawat Jalan Departemen Ilmu Penyakit Saraf Rumah Sakit Dr. Hasan Sadikin Bandung selama bulan November hingga Desember 2011 yang didiagnosis gangguan depresi. Subjek diperiksa dengan menggunakan instrumen Hamilton Depression Rating Scale (HDRS). Analisis korelasi dilakukan antara skor gejala gangguan depresi yang paling banyak terjadi dengan tipe TTH, dilanjutkan dengan analisis multivariabel untuk mencari rasio prevalens gejala gangguan depresi yang berkorelasi dengan tipe TTH. Angka kejadian gangguan depresi pada TTH didapatkan pada 32/38 penderita, sedangkan gejala gangguan depresi yang paling banyak ditemukan adalah suasana perasaan depresif, kelelahan/berkurangnya minat, dan ansietas psikis. Suasana perasaan depresif dan kelelahan/berkurangnya minat berkorelasi positif dengan tipe TTH $(r=0,411 ; p=0,019$ dan $r=0,379 ; p=0,032)$. Dari analisis regresi logistik, hanya suasana perasaan depresif yang meningkatkan risiko TTH kronik, yaitu sebesar 4,74 kali (IK 95\% 1,24-18,02). Simpulan, suasana perasaan depresif merupakan gejala yang paling banyak terjadi dan dapat digunakan untuk penapisan dini gangguan depresi pada penderita TTH serta meningkatkan risiko TTH kronik. [MKB. 2013;45(1):28-34]
\end{abstract}

Kata kunci: Gangguan depresi, gejala gangguan depresi, tension-type headache

\section{Relationship between Depressive Disorder Symptoms and the Tension-Type Headache (TTH): An Explorative Study}

\begin{abstract}
The prevalence rate of depressive disorders is increasing, including those having comorbidity with physical illnesses. One of the medical conditions that has been related to depressive disorder is tension-type headache (TTH). This comorbidity is related to the chronic course of TTH. This research aims to know which kind of depressive symptoms are most frequently found in TTH patients and to analyze the correlation between those symptoms and the type of TTH. This was a cross sectional study on $32 \mathrm{TTH}$ patients who visited the outpatient clinic of the Neurology Department of Dr. Hasan Sadikin Hospital Bandung during the period of November to December 2011 and who were diagnosed as having depressive disorder. They were examined using Hamilton Depression Rating Scale (HDRS). We correlated the scores of depressive disorder symptoms with the type of $\mathrm{TTH}$, followed by mutivariable analysis to find the prevalence ratio of depressive disorder symptoms which correlated with the type of TTH. The results showed the prevalence rate of depressive disorder in TTH was 32/38 patients while the most frequent depressive disorder symptoms of the subjects were depressive mood, fatigue and psychological anxiety. Depressive mood and fatigue were positively correlated with the type of TTH (rs $=0.411$, $\mathrm{p}=0.019$ and $\mathrm{rs}=0.379, \mathrm{p}=0.032$ ). Logistic regression analysis showed that only depressive mood increased the risk of chronic TTH with a prevalence ratio of 4.74 (IK 95\% 1.24-18.02). In conclusions, depressive mood, which is the most frequent symptoms of depressive disorder, can be used in the early screening of depressive disorder in TTH patients and this symptom increased the risk of chronic TTH. [MKB. 2013;45(1):28-34]
\end{abstract}

Key words: Depressive disorder, depressive disorder symptoms, tension-type headache

Korespondensi: Cecilia J. Setiawan, dr., SpKJ, M.Kes, Rumah Sakit Awal Bros, jalan MH. Thamrin No 3 Cikokol Tangerang 15117, mobile 083829993299, e-mail bonefishblue@yahoo.com 


\section{Pendahuluan}

Gangguan depresi merupakan suatu gangguan psikiatrik yang termasuk suasana perasaan dan dapat menyebabkan gangguan fungsi hubungan, interpersonal, sosial, ataupun pekerjaan. ${ }^{1}$ Gejala utama suasana perasaan depresif berupa perasaan sedih, putus asa, tidak berdaya, dan juga tidak berguna. Keluhan ini sering kali disertai dengan kesulitan dalam berkonsentrasi, pikiran bersalah, gangguan memori, pikiran akan kematian atau bunuh diri, minat dan kesenangan berkurang, kelelahan, motorik yang melambat, kegelisahan, terdapat gejala somatik seperti nyeri, ketegangan otot serta gejala vegetatif seperti gangguan tidur, kehilangan nafsu makan, penurunan berat badan, dan gangguan aktivitas seksual. ${ }^{1,2}$

Gangguan depresi dapat terjadi pada siapa saja dengan risiko yang lebih tinggi pada penderita penyakit fisik, yaitu sekitar $15-60 \%$. $^{3}$ Kondisi medis yang telah lama dikaitkan dengan gangguan depresi antara lain nyeri kepala primer tipe tegang atau tension-type headache (TTH). ${ }^{4}$ Nyeri kepala tipe ini merupakan nyeri kepala yang paling umum dialami oleh $30-78 \%$ masyarakat dan sampai saat ini patogenesisnya masih belum jelas dan bersifat multifaktorial. ${ }^{5-7}$ Gangguan depresi dapat terjadi bersama-sama dengan TTH sebagai komorbiditas dan berhubungan dengan awitan, perburukan, dan perjalanan nyeri kepala menjadi kronik, baik melalui proses biologik maupun psikologik. $^{8}$ Hasil wawancara dengan mempergunakan Mini International Neuropsychiatry Interview (MINI), sebanyak $68,3 \%$ penderita TTH akan mengalami episode depresif. ${ }^{4}$ Penderita TTH kronik akan mengalami depresi yang lebih berat dibandingkan dengan TTH episodik dan nyeri kepala kronik berhubungan dengan skor psikopatologi secara bermakna, tetapi arah hubungannya belum jelas. ${ }^{9}$ Komorbiditas gangguan depresi ini berhubungan dengan intensitas nyeri kepala yang lebih berat dan menetap, penurunan kualitas hidup, prognosis yang lebih buruk, menjadi menahunnya penyakit, ketidakpatuhan pengobatan, respons pengobatan yang lebih buruk, serta biaya pengobatan yang membesar. ${ }^{10}$

Berdasarkan survei pendahuluan, didapatkan data kunjungan penderita TTH di Instalasi Rawat Jalan Departemen Ilmu Penyakit Saraf Rumah Sakit Dr. Hasan Sadikin Bandung selama tahun 2010 sebanyak 1.302 orang. Jumlah penderita TTH yang dirujuk ke Instalasi Rawat Jalan Departemen Ilmu Kedokteran Jiwa Rumah Sakit Dr. Hasan Sadikin Bandung adalah 16 orang tanpa diketahui diagnosis gangguan jiwanya. Hasil ini mungkin menunjukkan bahwa angka kejadian komorbiditas gangguan psikiatrik pada penderita TTH masih rendah atau kurang terdeteksi. Hal ini dapat disebabkan oleh karena penderita tidak menujukkan gejala gangguan depresi yang khas atau tidak mengungkapkan permasalahan yang ada bila tidak ditanya. Oleh karena itu perlu diteliti mengenai gejala gangguan depresi yang banyak terjadi pada penderita TTH yang mengalami gangguan depresi dan menganalisis hubungannya dengan tipe TTH yang dialaminya, yaitu episodik atau kronik. Pengetahuan akan hal ini diharapkan dapat membantu para klinisi dalam mendeteksi gangguan depresi pada penderita TTH agar dapat memperoleh penatalaksanaan yang komprehensif dan holistik.

\section{Metode}

Subjek penelitian ini penderita TTH yang sedang berobat di Instalasi Rawat Jalan Departemen Ilmu Penyakit Saraf RS Dr. Hasan Sadikin Bandung (RSHS) yang dipilih secara consecutive sampling periode November-Desember 2011 dan bersedia ikut dalam penelitian ini setelah menandatangani perjanjian (informed consent). Kriteria inklusinya penderita berusia 20-50 tahun, didiagnosis TTH episodik atau kronik berdasarkan International Classification of Headache Disorders second Edition (ICHD-2), didiagnosis sebagai gangguan depresi berdasarkan kriteria diagnosis Pedoman Penggolongan \& Diagnosis Gangguan Jiwa Edisi III (PPDGJ-III), serta penderita mampu membaca huruf latin dan berbahasa Indonesia. Penderita yang menderita nyeri kepala tipe lain bersamasama dengan TTH, menderita penyakit fisik lain yang berat, sedang menjalani pengobatan untuk gangguan depresi, dan juga menderita gangguan psikotik tidak diikutsertakan dalam penelitian.

Penelitian ini dilakukan secara potong silang dengan besar sampel minimal sejumlah 30 orang penderita TTH yang juga mengalami gangguan depresi. Gejala gangguan depresi subjek diperiksa mempergunakan instrumen Hamilton Depression Rating Scale (HDRS) yang merupakan suatu alat ukur untuk menentukan beratnya gejala depresi berjumlah 17 butir yang dinilai berdasarkan skor 0-4 ( $0=$ tidak ada dan $4=$ paling berat), skor $0-3$ $(0=$ tidak ada dan $3=$ berat $)$ atau skor $0-2(0=$ tidak ada dan $2=$ berat). ${ }^{11}$

Data ini dianalisis dengan mempergunakan Statistical Package for the Social Science (SPSS) for Windows release 19.0. standard version. Uji Korelasi Rank Spearman dipakai dalam analisis bivariabel untuk menghitung korelasi skor gejala gangguan depresi yang paling banyak terjadi pada tipe TTH, kemudian dilanjutkan dengan analisis multivariabel regresi logistik untuk pengujian secara regresi skor gejala gangguan depresi yang paling banyak terjadi dengan tipe TTH, sehingga 
didapatkan rasio prevalens (interval kepercayaan 95\%). ${ }^{12}$

\section{Hasil}

Penderita TTH yang berobat jalan ke Instalasi Rawat Jalan Departemen Ilmu Penyakit Saraf RSHS periode bulan November-Desember 2011 berjumlah 65 orang yang berusia 20-78 tahun.
Sejumlah 38 penderita berada dalam rentang usia yang sesuai dengan kriteria inklusi penelitian dan 32 penderita di antaranya mengalami gangguan depresi.

Didapatkan korelasi positif bermakna antara gejala suasana perasaan depresif dan tipe TTH dengan $\mathrm{p}=0,019$ dan kekuatan korelasi sedang $\left(r_{s}=0,4-0,599\right)$ (Tabel 3). Gejala kelelahan atau minat berkurang dan tipe TTH juga mempunyai korelasi positif yang bermakna $(\mathrm{p}=0,341)$ dengan

\section{Tabel 1 Karakteristik Subjek Penderita TTH dengan Gangguan Depresi}

\begin{tabular}{|c|c|}
\hline Karakteristik & $\mathrm{n}=32$ \\
\hline Usia (tahun)* & $43(\mathrm{SB} \pm 9,4)$ \\
\hline \multicolumn{2}{|l|}{ Jenis kelamin } \\
\hline Perempuan & 20 \\
\hline Laki-laki & 12 \\
\hline \multicolumn{2}{|l|}{ Pendidikan } \\
\hline Tamat Sekolah Dasar (SD) & 7 \\
\hline Tamat Sekolah Menengah Pertama (SMP)/sederajat & 4 \\
\hline Tamat Sekolah Menengah Atas (SMA)/sederajat & 15 \\
\hline Tamat Perguruan Tinggi & 6 \\
\hline \multicolumn{2}{|l|}{ Status pernikahan } \\
\hline Belum menikah & 2 \\
\hline Menikah & 24 \\
\hline Bercerai/pasangan meninggal & 6 \\
\hline \multicolumn{2}{|l|}{ Pekerjaan } \\
\hline Tidak bekerja & 12 \\
\hline Bekerja & 20 \\
\hline \multicolumn{2}{|l|}{ Penghasilan" } \\
\hline Tidak ada & 12 \\
\hline$<\mathrm{UMK}$ & 7 \\
\hline >UMK & 13 \\
\hline \multicolumn{2}{|l|}{ Penyakit fisik lainnya } \\
\hline Ada & 21 \\
\hline Tidak ada & 11 \\
\hline \multicolumn{2}{|l|}{ Derajat gangguan depresi } \\
\hline Depresi ringan & 7 \\
\hline Depresi sedang & 23 \\
\hline Depresi berat & 2 \\
\hline \multicolumn{2}{|l|}{ Masalah stresor depresi } \\
\hline Keluarga & 18 \\
\hline Ekonomi & 6 \\
\hline Kesehatan & 6 \\
\hline Lain-lain & 2 \\
\hline Lama gangguan depresi (bulan)* & $5,8(\mathrm{SB} \pm 5,8)$ \\
\hline \multicolumn{2}{|l|}{ Tipe TTH } \\
\hline Episodik & 21 \\
\hline Kronik & 11 \\
\hline \multicolumn{2}{|l|}{ Intensitas nyeri } \\
\hline Ringan-sedang & 30 \\
\hline & $\begin{array}{l}\text { Pererat } \\
\text { Pemaian analgetik }\end{array}$ \\
\hline $\begin{array}{l}\text { Pemakaian analgetik } \\
\text { Tidak pakai }\end{array}$ & 4 \\
\hline Pakai & 28 \\
\hline \multicolumn{2}{|l|}{ Pemakaian profilaktik nyeri } \\
\hline Tidak pakai & 26 \\
\hline Pakai & 6 \\
\hline
\end{tabular}

* Data disajikan sebagai rata-rata $\left(\mathrm{SB}=\right.$ simpang baku), ${ }^{\#}$ Penghasilan dikelompokkan berdasarkan upah minimum kota (UMK) Bandung, yaitu Rp1.271.625,- 
Tabel 2 Gejala Gangguan Depresi pada Subjek

\begin{tabular}{clc}
\hline $\begin{array}{c}\text { Butir } \\
\text { Gejala }\end{array}$ & \multicolumn{1}{c}{ Gejala } & n=32 \\
\hline 1 & Suasana perasaan depresif & 32 \\
2 & Pikiran bersalah/berdosa & 24 \\
3 & Pikiran kematian/bunuh diri & 7 \\
4 & Insomnia initial & 17 \\
5 & Insomnia middle & 19 \\
6 & Insomnia late & 18 \\
7 & Kelelahan/minat berkurang & 32 \\
8 & Retardasi/perlambatan motorik & 24 \\
9 & Agitasi/kegelisahan & 26 \\
10 & Ansietas psikis & 32 \\
11 & Ansietas somatik & 31 \\
12 & Gejala somatik gastrointestinal & 22 \\
13 & Gejala somatik umum & 30 \\
14 & Gangguan aktivitas seksual & 17 \\
15 & Hipokondriasis & 30 \\
16 & Penurunan berat badan & 14 \\
17 & Insight/pemahaman diri & 24 \\
\hline
\end{tabular}

kekuatan korelasi lemah $(\mathrm{r}=0,2-0,399)$. Gejala ansietas psikis dan tipe TTH tidak mempunyai korelasi positif yang bermakna $(\mathrm{p}=0,341)$.

Setelah dilakukan uji analisis multivariabel, hanya gejala suasana perasaan depresif yang tetap memiliki korelasi positif yang bermakna dengan tipe TTH $(p=0,023)$ dan rasio prevalens gejala tersebut menunjukkan angka $>1$ dengan rentang interval kepercayaan tidak mencakup angka 1 . Hal ini menunjukkan bahwa subjek dengan gejala suasana perasaan depresif mempunyai risiko 4,74 kali lebih besar mengalami TTH kronik (Tabel 4).

\section{Tabel 3 Korelasi antara Gejala Gangguan Depresi yang Paling Banyak Terjadi dan Tipe TTH}

\begin{tabular}{lcc}
\hline Gejala Gangguan Depresi & \multicolumn{2}{c}{ Tipe TTH } \\
\cline { 2 - 3 } yang Paling Banyak Terjadi & $\mathbf{r}_{\mathrm{s}}$ & $\mathbf{p}$ \\
\hline Suasana perasaan depresif & 0,411 & $0,019^{*}$ \\
Kelelahan/berkurangnya minat & 0,379 & $0,032^{*}$ \\
Ansietas psikis & 0,174 & 0,341 \\
\hline
\end{tabular}

$\mathrm{r}_{\mathrm{s}}=$ koefisien Korelasi Rank Spearman, *Kemaknaan ditetapkan berdasarkan $\mathrm{p} \leq 0,05$

\section{Pembahasan}

Angka kejadian gangguan depresi pada penderita TTH selama periode penelitian ini sebesar 32/38 penderita lebih besar daripada penelitian oleh Beghi dkk. ${ }^{4}$ yang mendapatkan hasil $68,3 \%$ serta Matta dan Moriera-Filho ${ }^{13}$ yang membuktikan gejala depresi pada $32 \%$ penderita TTH episodik dan pada $40 \%$ penderita TTH kronik. Perbedaan hasil ini mungkin disebabkan oleh subjek yang diteliti dibatasi yang berusia $20-50$ tahun. Jumlah penderita TTH yang datang berobat sebenarnya lebih banyak, tetapi usianya $>50$ tahun sehingga tidak memenuhi kriteria inklusi pada penelitian ini. Angka komorbiditas yang tinggi ini dapat menunjukkan bahwa perlu penapisan gangguan depresi pada semua penderita TTH tipe episodik maupun kronik serta dilakukan penatalaksanaan yang adekuat. Bila keadaan ini diabaikan dapat menghambat penatalaksanaan secara simtomatik dan profilaktik gangguan depresi serta kualitas

Tabel 4 Analisis Multivariabel Gejala Suasana Perasaan Depresif dan Kelelahan atau Minat Berkurang dengan Tipe TTH

\begin{tabular}{|c|c|c|c|c|c|c|c|c|}
\hline \multirow{2}{*}{ Model } & \multirow{2}{*}{$\begin{array}{c}\text { Variabel } \\
\text { Dependen }\end{array}$} & \multirow{2}{*}{$\begin{array}{c}\text { Variabel } \\
\text { Independen }\end{array}$} & \multirow{2}{*}{ Koef } & \multirow{2}{*}{ SE } & \multirow{2}{*}{$\mathbf{p}$} & \multirow{2}{*}{$\mathbf{R P}$} & \multicolumn{2}{|c|}{$95 \%$ IK } \\
\hline & & & & & & & Min & Maks \\
\hline \multirow[t]{3}{*}{ Awal } & $\begin{array}{l}\text { Tipe TTH } \\
\text { (kronik } \\
\text { dan } \\
\text { episodik) }\end{array}$ & $\begin{array}{l}\text { Suasana } \\
\text { perasaan } \\
\text { depresif }\end{array}$ & 1,416 & 0,768 & 0,065 & 4,12 & 0,92 & 18,56 \\
\hline & & $\begin{array}{l}\text { Kelelahan/ } \\
\text { minat } \\
\text { berkurang }\end{array}$ & 0,991 & 0,703 & 0,159 & 2,69 & 0,68 & 10,69 \\
\hline & & Konstanta & $-4,815$ & & & & & \\
\hline \multirow[t]{2}{*}{ Akhir } & $\begin{array}{l}\text { Tipe TTH } \\
\text { (kronik } \\
\text { dan } \\
\text { episodik) }\end{array}$ & $\begin{array}{l}\text { Suasana } \\
\text { perasaan } \\
\text { depresif }\end{array}$ & 1,555 & 0,682 & $0,023 *$ & 4,74 & 1,24 & 18,02 \\
\hline & & Konstanta & $-2,896$ & & & & & \\
\hline
\end{tabular}

*Nilai $\mathrm{p}$ dihitung berdasarkan uji regresi logistik multipel, bermakna bila $\mathrm{p} \leq 0,05, \mathrm{SE}=$ Standard error, $\mathrm{RP}=\mathrm{Rasio}$ prevalens, $\mathrm{IK}=$ Interval kepercayaan 
hidup penderita semakin menurun. ${ }^{13}$

Pada penelitian ini telah ditemukan bahwa sebagian besar penderita gangguan depresi pada TTH adalah perempuan dengan usia rata-rata 43 tahun $(\mathrm{SB} \pm 9,4)$. Hasil ini sesuai dengan literatur lain yang menyatakan bahwa penderita gangguan depresi pada populasi umum lebih banyak terjadi pada perempuan dibandingkan dengan laki-laki, usia awitan rata-rata 40 tahun dan $50 \%$ penderita mengalami gangguan depresi pada rentang usia 20-50 tahun. ${ }^{1,2}$ Skor HDRS ditemukan meningkat pada penderita TTH perempuan. ${ }^{14} \mathrm{Hal} \mathrm{ini} \mathrm{mungkin}$ disebabkan karena perempuan berfungsi ganda baik sebagai ibu rumah tangga maupun pencari nafkah yang dapat menjadi faktor risiko gangguan depresi. Reaksi mereka terhadap kejadian penting dalam kehidupan, khususnya yang terkait anak dan relasi, dapat mempunyai makna yang lebih dalam dan selanjutnya berakibat yang lebih besar dibandingkan dengan laki-laki. ${ }^{15}$

Data karakteristik lainnya yang mendukung yaitu kebanyakan penderita sudah menikah dan bekerja. Beban yang harus ditanggung membuat mereka lebih rentan untuk mengalami gangguan psikiatrik yaitu gangguan depresi atau penyakit fisik berupa TTH. ${ }^{2}$ Mereka yang telah menikah khususnya dapat menampilkan kesehatan mental yang lebih baik dibandingkan dengan yang belum menikah, tetapi kenyataannya perempuan yang telahmenikah berhubungan dengan angkakejadian gangguan depresi yang lebih tinggi dibandingkan dengan laki-laki. Hal ini membuktikan bahwa mungkin pada sebagian orang pernikahan dapat menjadi faktor predisposisi gangguan depresi, namun pada sebagian orang dapat menjadi faktor protektif. $^{15}$

Sebagian besar subjek berpendidikan SMA dan bekerja dengan berpenghasilan di atas UMK. Literatur lain menyatakan bahwa tidak terdapat hubungan status sosioekonomi dengan gangguan depresi, ${ }^{1}$ tetapi sumber lain menyatakan bahwa faktor sosial seperti kemiskinan, tidak bekerja, dan kondisi lingkungan yang buruk berkontribusi pada terjadinya gangguan depresi. ${ }^{15}$ Pekerjaan dapat menjadi faktor protektif sekaligus faktor risiko untuk gangguan depresi. Menganggur jelas merupakan faktor risiko gangguan depresi karena tidak ada penghasilan, harga diri menurun, dan dukungan sosial berkurang. ${ }^{15}$

Gangguan depresi yang dialami oleh sebagian besar subjek, yaitu derajat sedang sampai berat sesuai dengan hasil penelitian yang dilakukan oleh Matta dan Moreira-Filho. ${ }^{13}$ Hal ini tentunya harus menjadi perhatian klinisi karena derajat depresi berhubungan dengan kronisitas TTH. Penelitian oleh Cassidy dkk. ${ }^{9}$ mendapatkan penderita sering nyeri kepala kronik dan mengalami depresi yang lebih berat bila dibandingkan dengan nyeri kepala episodik.

Masalah keluarga merupakan masalah yang dialami oleh lebih setengah subjek penelitian, diikuti masalah ekonomi dan kesehatan. Masalah kesehatan bukanlah merupakan faktor pencetus utama gangguan depresi pada subjek ini, namun dalam penelitian lain ditemukan hubungan kuat antara awitan penyakit fisik dan risiko gangguan depresi yang meningkat sampai tiga kali lipat. Pada awitan terjadi disabilitas akibat penyakit fisik merupakan faktor risiko yang kuat terjadinya gangguan depresi dan sering kali disertai dengan kehilangan produktivitas, kontrol lingkungan, dan kemandirian, serta tidak mampu melakukan aktivitas sehari-hari. ${ }^{15}$

Gangguan depresi yang terjadi pada subjek dapat bersifat primer (berdiri sendiri) maupun sekunder akibat TTH yang dialaminya. Lama gangguan depresi yang dialami subjek rata-rata 5,8 bulan. Hal ini membutuhkan perhatian yang serius, oleh karena selama kurun waktu tersebut penderita tidak mendapatkan bantuan profesional untuk gangguan depresinya. Meskipun dikatakan bahwa gangguan depresi dapat mengalami remisi tanpa pengobatan dalam waktu 6-24 bulan, tetapi selama perjalanan penyakit dapat menyebabkan gangguan fungsi aspek kehidupan penderita, sehingga dapatmemperberat gangguan depresinya atau gangguan lain yang berkomorbiditas seperti $\mathrm{TTH}^{2}{ }^{2}$

Sebagian besar subjek penelitian didiagnosis TTH kronik. Faktor yang dapat memperburuk nyeri kepala kronik dan sering terlupakan salah satunya stres emosional dan faktor psikososial. ${ }^{14}$ Pada praktik klinis, penderita TTH sangat sering melaporkan ketegangan, kelelahan mental, dan stres sebagai faktor pencetus untuk nyeri kepala mereka. Faktor pencetus ini dialami oleh sekitar $56-70,1 \%$ subjek dalam beberapa penelitian. ${ }^{16}$

Semua penderita mengalami gejala perasaan depresif yang merupakan gejala utama gangguan depresi sesuai dengan kriteria diagnosis PPDGJIII. Gejala ini ditandai dengan perasaan sedih, murung, putus asa, atau tidak berharga. ${ }^{1}$ Rata-rata subjek TTH episodik baru menyatakan perasaan ini bila ditanya, sedangkan penderita TTH kronik menyatakan perasaan ini secara verbal spontan. Hal ini dapat menunjukkan bahwa para klinisi perlu melakukan penapisan dini gangguan depresi secara aktif oleh karena kemungkinan penderita enggan membicarakan masalahnya apabila tidak ditanya terlebih dahulu, terutama pada penderita TTH episodik. Gejala suasana perasaan depresif berkorelasi positif dengan penderita TTH bahkan setelah dilakukan analisis multivariabel penderita dengan gejala ini memiliki risiko 4,74 kali lebih besar untuk mengalami TTH kronik. Peranan awal para klinisi dalam mengevaluasi penderita 
nyeri kronik yaitu menilai sampai sejauh mana penderita akan merasa sedih serta putus asa akibat kejadian bermakna yang datang beruntun, merasa kecewa akibat kerentanan psikologisnya sendiri sehingga berulang kali memilih untuk melakukan perilaku yang bermasalah atau merasakan sakit akibat penyakit tertentu. Model kognitif perilaku dari nyeri kronik menganggap bahwa persepsi seseorang dan penilaian pengalaman kehidupan memengaruhi reaksi emosional dan juga perilaku terhadap pengalaman ini. Jika penderita merasa yakin bahwa nyeri, depresi, dan disabilitas tidak dapat dicegah dan dikontrol, maka mereka akan mengalami respons afektif yang lebih negatif, nyeri yang meningkat dan makin kronik, serta bahkan lebih banyak gangguan fungsi fisik dan psikososial. Keadaan emosional negatif dapat memperburuk pengalaman nyeri dan sebaliknya. Pengaruh dua arah emosi pada nyeri menunjukkan bahwa emosi memengaruhi dan dipengaruhi oleh biologi, kognisi, kepribadian, perilaku nyeri, pembelajaran, dan juga lingkungan sosial. Emosi memperkuat serta memperpanjang pengalaman nyeri dan memengaruhi hasil penanganan nyeri. ${ }^{10}$

Kelelahan atau berkurangnya minat dialami oleh semua penderita. Rata-rata penderita TTH episodik menyatakan kehilangan minat terhadap pekerjaan atau hobi, ragu-ragu, lesu, dan bimbang, sedangkan penderita yang memiliki TTH kronik menyatakan berkurangnya waktu untuk aktivitas sehari-hari atau produktivitas (minimal tiga jam dalam kegiatan sehari-hari). Gejala ini dapat tumpang tindih dengan TTH, karena penderita TTH juga sering mengalami kelelahan. ${ }^{17}$ Gejala kelelahan atau minat berkurang ini berkorelasi positif dengan tipe TTH, yaitu semakin berat gejala ini, maka makin kronik TTH yang dialami penderita. Korelasi ini ditiadakan setelah gejala ini dianalisis secara multivariabel bersama-sama dengan suasana perasaan depresif. Oleh karena itu, gejala ini perlu mendapatkan perhatian karena dapat menurunkan produktivitas sehari-hari dan kualitas hidup penderita akibat gangguan depresi maupun kronisitas TTH yang dialaminya.

Ansietas psikis juga dapat dialami oleh semua penderita, yaitu sering mengkhawatirkan hal-hal yang kecil, baik pada penderita TTH episodik maupun kronik. Hal ini menunjukkan tingginya kejadian gangguan depresi bentuk lainnya selain yang tipikal pada penderita TTH, yaitu berbentuk neurotik. Bentuk ini tidak begitu berat namun lebih kronik dan tidak terlalu responsif dengan terapi antidepresan, sehingga lebih mendapatkan manfaat dari pemberian psikoterapi. ${ }^{2}$ Temuan ini juga dapat menunjukkan kemungkinan lain, yaitu komorbiditas gangguan cemas selain gangguan depresi yang tidak dieksklusikan dalam penelitian ini.
Meskipun tidak dialami oleh semua penderita, pikiran bersalah atau berdosa dialami oleh 3 dari 4 penderita. Mereka kebanyakan memiliki ide-ide bersalah atau renungan tentang kesalahan masa lalu. Karakteristik utama pikiran depresif adalah penderita memandang segala sesuatu dari sudut pandang yang negatif. Mereka memiliki citra diri yang buruk, tidak berharga, dan mencerminkan persepsinya terhadap gangguan akibat terjadinya perlambatan motorik. ${ }^{1}$ Hal ini perlu mendapatkan perhatian oleh karena dapat memengaruhi persepsi penderita terhadap nyeri kepala yang dialaminya dan dapat mengganggu pengobatan yang sedang dijalaninya. Tidak jarang gejala ini mengarah pada pikiran akan kematian sehingga perlu dilakukan pencegahan. Pikiran akan kematian atau bunuh diri hanya dialami oleh 7 orang penderita namun perlu mendapatkan perhatian khusus. Sebanyak 3 orang penderita bahkan pernah mengharapkan kematian atau pikiran-pikiran ke arah itu. Sekitar $15 \%$ penderita yang mempunyai gejala depresi berat, pada akhirnya mereka akan melakukan bunuh diri. Percobaan bunuh diri mencapai angka 10 setiap 100 penderita depresi per tahunnya, dengan usaha bunuh diri yang berhasil setiap 100 penderita depresi per tahunnya meskipun belum tentu berhubungan dengan gangguan depresinya. Kondisi ini biasanya akan terjadi bila gangguan depresi tidak diterapi. ${ }^{2}$ Berdasarkan hal tersebut maka penapisan gangguan depresi pada penderita TTH perlu dilakukan. Para klinisi harus selalu waspada terhadap akan kemungkinan bunuh diri pada semua penderita dengan gangguan depresi. ${ }^{1}$

Simpulan, didapatkan korelasi positif gejala gangguan depresi yang banyak ditemukan, yaitu suasana perasaan depresif dan minat berkurang atau kelelahan dengan tipe TTH. Terdapat pula hubungan antara suasana perasaan depresif dan tipe TTH yang dianggap sebagai salah satu faktor risiko TTH tipe kronik. Temuan ini menunjukkan bahwa perlunya dilakukan suatu upaya penapisan dini gangguan depresi secara rutin pada penderita TTH dengan mencari gejala gangguan depresi yang banyak terjadi atau menggunakan alat ukur seperti MINI atau Patient Health Questionairre 9 (PHQ-9). Keadaan ini dapat tercapai melalui kerjasama yang baik antara Departemen Ilmu Penyakit Saraf dan Ilmu Kedokteran Jiwa, juga dalam tatalaksana komprehensif penderita TTH yang memiliki komorbiditas gangguan depresi sehingga mencegah prognosis yang kurang baik dan meningkatkan kualitas hidup penderita.

\section{Daftar Pustaka}

1. Sadock BJ, Sadock VA. Kaplan \& Sadock's Synopsis of psychiatry: behavioural sciences/ 
clinical psychiatry. Edisi ke-10. Philadelphia: Lippincott Williams \& Wilkins; 2007.

2. Stahl SM. Essential psychopharmacology: neuroscientific basis and practical applications. Edisi ke-2. Cambridge: Cambridge University Press; 2000.

3. MacHale S. Managing depression in physical illness. Adv Psych Treat. 2002;8:297-306.

4. Beghi E, Allais G, Cortelli P, D'Amico D, De Simone R, d'Onofrio F, dkk. Headache and anxiety-depressive disorder comorbidity: the HADAS study. Neurol Sci. 2007;28(Suppl 2):S217-9.

5. Markley HG. Classification and diagnosis of chronic daily headache and tension-type headache. Dalam: Levin $\mathrm{M}$, penyunting. Comprehensive review of headache medicine. New York: Oxford University Press; 2008. hlm. 73-90.

6. Solomon GD. Chronic tension-type headache: advice for the viselike-headache patient. Cleve Clin J Med. 2002;69(2):16772.

7. Schoenen J. Introduction. Dalam: Fernandez-de-las-Penas C, Arendt-Nielsen L, Gerwin RD, penyunting. Tension-type and cervicogenic headache: pathophysiology, diagnosis, and management. Massachusetts: Jones and Barrlett Publishers; 2010. hlm. $3-5$.

8. Baskin SM. Psychiatric comorbidity and causes of headache. Dalam: Levin $M$, penyunting. Comprehensive review of headache medicine. New York: Oxford University Press; 2008. hlm. 193-206.

9. Cassidy EM, Tomkins E, Hardiman O, O'Keane V. Factors associated with burden of primary headache in a specialty clinic. Headache. 2003;43(6):638-44.

10. Clark MR, Treisman GJ. Pain and depression: an interdisciplinary patient-centered approach. Basel: Karger; 2004.

11. Sajatovic M, Ramirez LF. Rating scales in mental health. Hudson: Lexi Comp Inc; 2001.

12. Dahlan MS. Besar sampel dalam penelitian kedokteran dan kesehatan. Jakarta: PT Arkans; 2005.

13. Matta AP, Moreira-Filho PF. Depressive symptoms and anxiety in patients with chronic and episodic tension-type headache. Arq Neuropsiquiatr. 2003;61(4):991-4.

14. Silberstein SD, Lipton RB. Chronic daily headache, including transformed migraine, chronic tension-type headache, and medication overuse. Dalam: Silberstein SD, Lipton RB, Dalessio DJ, penyunting. Wolff's headache and other head pain. Edisi ke-7. New York: Oxford University Press; 2001. hlm. 247-82.

15. Stansfeld S, Rasul F. Psychosocial factors, depression and illness. Dalam: Steptoe A, penyunting. Depression and physical illness. New York: Cambridge University Press; 2007. hlm. 19-49.

16. Torelli P, Abrignani G, Castellini P, Lambru G, Manzoni GC. Human psyche and headache: tension-type headache. Neurol Sci. 2008;29(Suppl 1):S93-5.

17. Smitherman TA, Maizels M, Penzien DB. Headache chronification: screening and behavioral management of comorbid depressive and anxiety disorders. Headache. 2008;48(1):45-50. 